\title{
PENGARUH PERCEIVED QUALITY, PERCEIVED SACRIFICE, PERCEIVED VALUE, DAN PRICE FAIRNESS TERHADAP CUSTOMER SATISFACTION TAMAN SARI RASA WATERPARK CILACAP
}

\author{
Viola Amdya Rifqi \\ Universitas Muhammadiyah Purwokerto \\ Hermin Endratno \\ Universitas Muhammadiyah Purwokerto
}

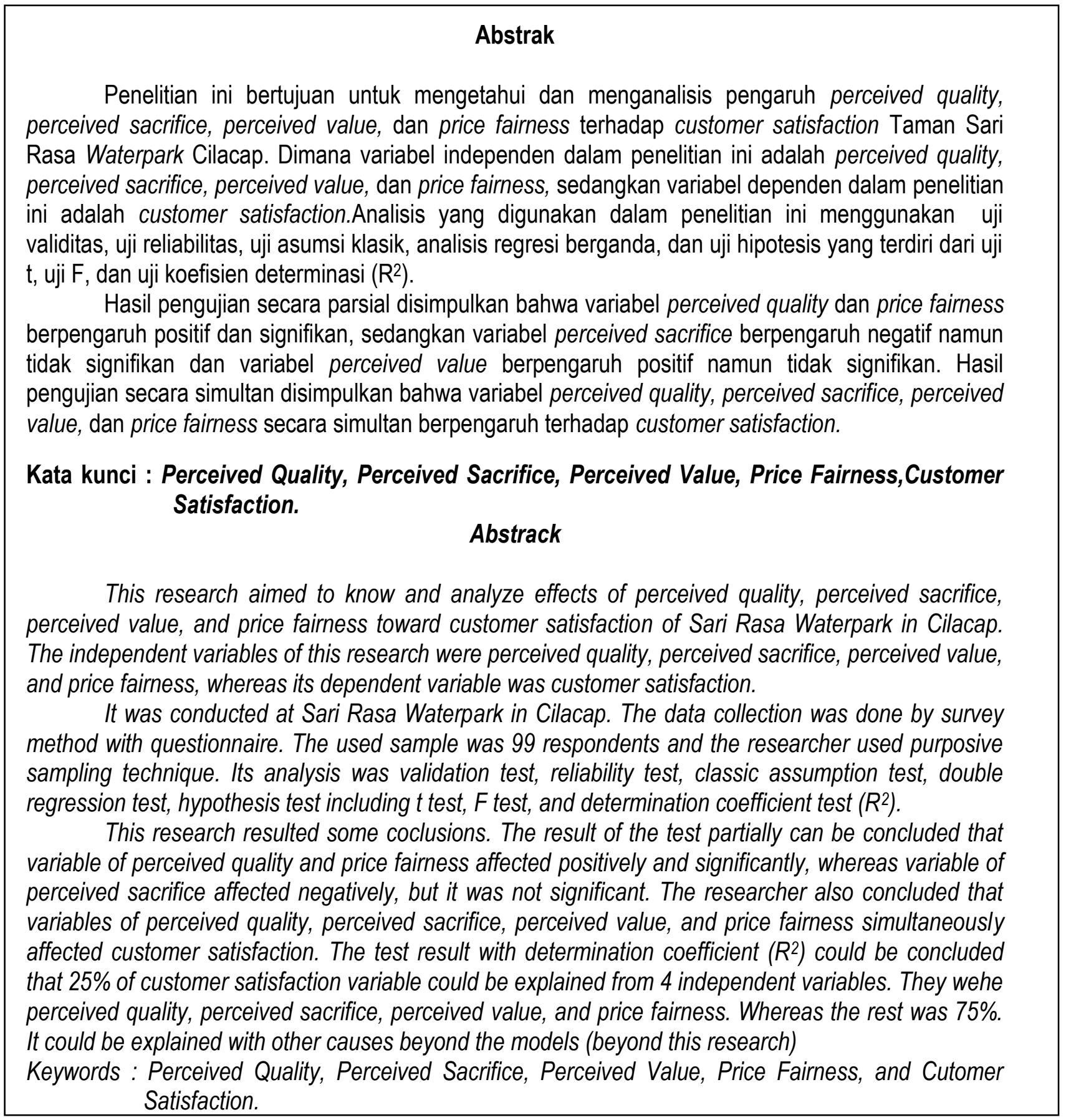




\section{I.PENDAHULUAN}

Salah satu cara masyarakat dalam memberikan kenyamanan dan melepas penat yaitu dengan rekreasi. Waterpark merupakan salah satu bentuk objek rekreasi. Waterpark atau taman bermain air banyak bermunculan dewasa ini, waterpark dibangun sebagai jawaban atas tuntutan inovasi dalam persaingan di dunia taman hiburan, serta jawaban atas tuntutan beragam kemudahan yang dicari oleh masyarakat yaitu sebagai sarana bermain yang edukatif sekaligus menghibur.Pihak manajemen waterpak perlu memperhatikan Perceived Quality, Perceived Sacrifice, Perceived Value, Price Fairness dan Cutomer Satisfaction.

Menurut Aaker (1997) dalam Krisno dan Samuel (2013) perceived quality dapat didefinisikan sebagai persepsi pelanggan terhadap seluruh kualitas atau keunggulan suatu produk atau jasa layanan sehubungan dengan maksud yang diharapkan. Penelitian yang dilakukan Ayu (2009) dengan judul Pengaruh Perceived Quality, Perceived Value, Brand Preference, Customer Satisfaction, dan Customer Loyalty pada Repurchase Intention menemukan bukti bahwa variabel Perceived Quality memiliki pengaruh positif dan signifikan terhadap Customer Satisfaction.

Persepsi pengorbanan (perceived sacrifice) adalah hal-hal yang menurut konsumen harus diberikan atau dikorbankan untuk mendapatkan suatu produk baik finansial maupun non finansial.Pengorbanan yang dimaksud dapat dibedakan menjadi pengorbanan materi dan non materi (Zeithmal dan Bitner, 1996 dalam Sutanto, 2010). Penelitian yang dilakukan Krisno dan Samuel (2013) dengan judul Pengaruh Perceived Quality, Perceived Sacrifice, Perceived Value terhadap Customer Satisfaction di Informa Innovative menemukan bukti bahwa variabel Perceived Sacrifice memiliki pengaruh negatif terhadap Customer Satisfaction.

Perceived value (nilai yang dipersepsikan) dapat juga berarti usaha konsumen membandingkan produk/jasa dari perusahaan tertentu dengan perusahaan pesaing ditinjau dari manfaat, kualitas, dan harga (Aaker, 1997 dalam Krisno dan Samuel 2013). Penelitian yang dilakukan Herwinarni dan Gunistiyo dengan judul Pengaruh Persepsi Nilai, Persepsi Kualitas dan Citra Perusahaan Terhadap Kepuasan dan Loyalitas Konsumen pada Rumah Makan "Indonesia" di kota Tegal menunjukan bahwa variabel Perceived Valuememiliki pengaruh positif dan signifikan terhadap Customer Satisfaction.

Price fairness(kewajaran harga) melibatkan perbandingan prosedur harga yang terkait dengan standar, referensi atau norma (Consuegra et al., 2007 dalam Nurdiansah, 2013). Penelitian yang dilakukan Adi (2013) dengan judul Pengaruh Kualitas Produk dan Kewajaran Harga Terhadap Loyalitas dengan Kepuasan Konsumen Sebagai Variabel Intervening menunjukan bahwa variabel Price Fairness memiliki pengaruh positif dan signifikan terhadap Customer Satisfaction.

Menurut Kotler (2009) secara umum Customer Satisfaction(kepuasan pelanggan) adalah perasaan senang atau kecewa seseorang yang muncul setelah membandingkan kinerja (hasil) produk atau jasa yang dipikirkan terhadap kinerja (atau hasil) yang diharapkan.Jika kinerja memenuhi harapan, pelanggan puas. Jika kinerja melebihi harapan, pelanggan amat puas atau senang.

Penelitian ini adalah pengembangan dari penelitian Krisno \&Samuel (2013) yang berjudul "Pengaruh Perceived Quality, Perceived Sacrifice dan Perceived Value terhadap Customer Satisfaction di Informa Innovative Furnishing Pakuwon City Surabaya". Tujuannya adalah untuk menguji kembali apakah model yang dikemukakan Krisno dan Samuel cukup relevan digunakan untuk mengukur Customer Satisfaction. Perbedaan dalam penelitian yang dikembangkan adalah dengan menambahkan variabelPrice Fairness dan mengganti objek yang berbeda yaitu di Taman Sari Rasa Waterpark Cilacap.

Berdasarkan uraian di atas maka dirumuskan judul penelitian sebagai berikut: "Pengaruh Perceived Quality, Perceived Sacrifice, Perceived Value, dan Price Fairnessterhadap Customer Satisfaction di Taman Sari Rasa Waterpark Cilacap". Rumusan masalahnya (1) apakah perceived quality, perceived value, price fairness berpengaruh positif terhadap Customer Satisfaction di Taman Sari Rasa Waterpark Cilacap, (2) apakah perceived sacrifice berpengaruh negatif terhadap 
customer satisfaction di Taman Sari Rasa Waterpark Cilacap ? (3) apakah Perceived Quality, Perceived Sacrifice, Perceived Value, dan Price Fairness berpengaruh secara simultan terhadap Customer Satisfactiondi Taman Sari Rasa Waterpark Cilacap ? Penelitian ini hanya dilakukan di Taman Sari Rasa Waterpark Cilacap dengan ukuran sampel 100 responden, yang berumur minimal 16 tahun dan pernah berkunjung ke Taman Sari Rasa Waterpark minimal 1 kali.

\section{II.TINJAUAN PUSTAKA}

\section{A.Manajemen Pemasaran}

Manajemen pemasaran (marketing management) menurut Kotler (2009) sebagai seni dan ilmu memilih pasar sasaran dan meraih, mempertahankan, serta menumbuhkan pelanggan dengan menciptakan, menghantarkan, dan mengomunikasikan nilai pelanggan yang unggul. Menurut Kotler dan Amstrong (2003) proses itu melibatkan lebih dari sekedar mendapat cukup pelanggan bagi outputperusahaan saat ini. Pemasaran dalam waktu tertentu juga berurusan dengan mengubah/bahkan mengurangi permintaan.

\section{B.Perceived Quality}

Kualitas (quality) adalah totalitas fitur dan karakteristik produk atau jasa yang tergantung pada kemampuannya untuk memuaskan kebutuhan yang dinyatakan atau tersirat (Kotler, 2009).Menurut Tjiptono (2007) definisi Perceived Qualityberfokus pada upaya pemenuhan kebutuhan dan keinginan pelanggan, serta ketetapan penyampaiannya untuk mengimbangi harapan pelanggan. Persepsi kualitas yang baik/positif diperoleh bila kualitas yang dialami (experienced quality) memenuhi harapan pelanggan (expected quality). Bila harapan pelanggan tidak realistis, maka persepsi kualitas total ( total perceived quality) akan rendah. Sekalipun kualitas yang dialami memang baik ( diukur dengan berbagai ukuran objektif).

\section{C.Perceived Sacrifice}

Persepsi pengorbanan adalah hal-hal yang menurut konsumen harus diberikan atau dikorbankan untuk mendapatkan suatu produk baik finansial maupun non finansial.Pengorbanan yang dimaksud dapat dibedakan menjadi pengorbanan materi dan non materi.Pengorbanan materi tidak hanya berkisar pada harga pembelian namun juga pada biaya lain untuk mendapatkan produk tersebut (Zeithmal dan Bitner, 1996 dalam Sutanto, 2010).

Persepsi pengorbanan dari seorang konsumen akan semakin besar jika pengorbanan yang dilakukan untuk mendapatkan produk tersebut semakin besar. Jadi persepsi pengorbanan konsumen akan berbanding lurus dengan pengorbanan untuk mendapatkan suatu produk/jasa tersebut (Kotler, 2000 dalam Sutanto, 2010).

\section{D.Perceived Value}

Perceived value customer atau delivered value (nilai yang diterima pelanggan), menurutKotler (2000) dalam Sutanto (2010) adalah selisih antara total customer value (jumlah nilai bagi pelanggan)dan total customer cost (biaya total bagi pelanggan). Total customer value (jumlahnilai bagi pelanggan) adalah kumpulan manfaat yang diharapkan diperoleh pelanggandari produk atau jasa tertentu. Total customer cost (biaya total bagi pelanggan) adalahkumpulan biaya yang diperkirakan pelanggan akan terjadi dalam mengevaluasi,memperoleh, dan menggunakan produk atau jasa tersebut.

\section{E.Price Fairness}

Dalam mengevaluasi kepuasan harga, perusahaan sebaiknya mengenal lebih jauh harga yang dipersepsikan dalam benak pelanggan.Hal ini senada dengan Kotler dan Keller (2009) bahwa pemahaman harga merupakan prioritas pemasaran yang penting. Berikut ini tiga topik utama mengenai harga, yaitu:

a. Harga referensi

Riset memperlihatkan bahwa meskipun pelanggan mungkin mempunyai pengetahuan yang cukup banyak tentang kisaran harga yang terlibat, ternyata hanya sedikit pelanggan yang dapat 
mengingat harga spesifik produk secara akurat.Harga referensi (reference price) yaitu membandingkan harga yang diteliti dengan harga referensi internal yang mereka ingat atau dengan kerangka referensi eksternal seperti harga eceran regular yang terpasang.

b. Asumsi harga-kualitas

Produk yang memiliki harga yang mahal, sering diasumsikan memiliki kualitas tinggi.Dalam hal ini persepsi pelanggan dalam melihat harga dapat berbeda dari realitas sebenarnya.

c. Akhiran harga

Banyak penjual yakin bahwa harga harus berakhiran ganjil, misalnya Rp 99.999,00 Hal ini dilakukan untuk memainkan psikologi pelanggan, bahwa harga tersebut dipersepsikan oleh pelanggan sebagai potongan harga atau harga yang murah.

\section{F.Customer Satisfaction}

Kepuasan (satisfaction) adalah perasaan senang atau kecewa seseorang yang timbul karena membandingkan kinerja yang di persepsikan produk (atau hasil) terhadap ekspektasi mereka. Jika kinerja gagal memenuhi ekspektasi, pelanggan akan tidak puas. Jika kinerja sesuai dengan ekspektasi, pelanggan akan puas. Jika kinerja melebihi melebihi ekspektasi, pelanggan akan sangat puas atau senang (Kotler, 2009). Menurut Tjiptono (2007) berpendapat bahwa kepuasan pelanggan merupakan respons emosional terhadap pengalaman-pengalaman berkaitan dengan produk atau jasa tertentu yang dibeli, gerai ritel, atau bahkan pola perilaku (seperti perilaku berbelanja dan perilaku pembeli), serta pasar secara keseluruhan.

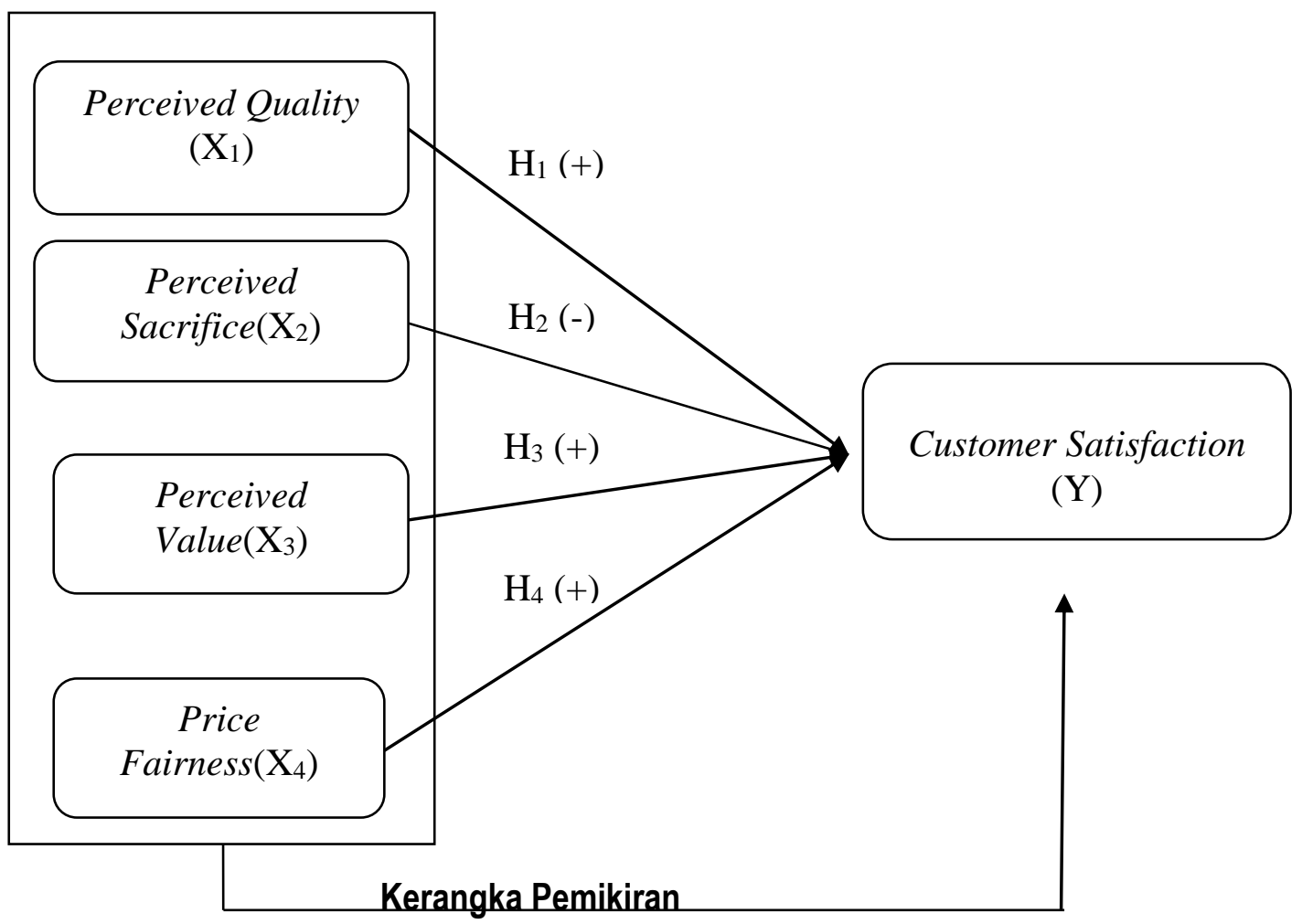

\section{Hipotesis Penelitian}

$\mathrm{H}_{1}$ :Perceived Quality berpengaruh positif terhadap Customer Satisfaction.

$\mathrm{H}_{2}$ : Perceived Sacrifice berpengaruh negatif terhadap Customer Satisfaction.

$\mathrm{H}_{3}$ : Perceived Value berpengaruh positif terhadap Customer Satisfaction.

$\mathrm{H}_{4}$ : Price Fairnessberpengaruh positif terhadap Customer Satisfaction.

$\mathrm{H}_{5}$ : Perceived Quality, Perceived Sacrifice, Perceived Value, dan Price Fairnessberpengaruh secara simultan terhadapCustomer Satisfactiondi Taman Sari Rasa Waterpark Cilacap 


\section{III.METODE PENELITIAN}

\section{A.Jenis Penelitian}

Jenis penelitian yang digunakan adalah metode survey, dengan mengambil sampel dari satu populasi dan menggunakan kuesioner sebagai alat pengumpul data yang pokok (Singarimbun dan Effendi, 2008).Penelitian ini digunakan untuk menjelaskan pengaruh antar variabel melalui pengujian hipotesis berdasarkan data yang diperoleh dari responden.

\section{B.Objek Penelitian}

Objek yang diteliti dalam penelitian ini adalah pengaruh perceived quality, perceived sacrifice, perceived value dan price fairness terhadap customer satisfaction di Taman Sari Rasa Waterpark Cilacap.

\section{C.Populasi dan Sampel Populasi}

Populasi adalah wilayah generalisasi yang terdiri atas obyek atau subyek yang mempunyai kualitas dan karakteristik tertentu yang ditetapkan oleh peneliti untuk dipelajari dan kemudian ditarik kesimpulannya (Sugiyono, 2004).Populasi dalam penelitian ini adalah pengunjung Taman Sari Rasa Waterpark Cilacap.

\section{Sampel}

Dalam penelititan ini, penulis tidak meneliti semua pelanggan dari Taman Sari Rasa Waterpark secara keseluruhan melainkan penulis cukup mengambil sampel yang telah ditentukan, yaitu pelanggan yang berumur minimal 16 tahun.Dengan demikian ukuran sampel minimal yang akan digunakan dalam penelitian ini adalah 96 responden. Namun untuk mengantisipasi kemungkinan adanya kuesioner yang tidak kembali/rusak, peneliti akan mengambil sebanyak 100 responden.

\section{Teknik Sampling}

Penentuan pengambilan sampel dalam penelitian ini menggunakanNon Probability Sampling, yaitu semua elemen dalam populasi tidak memiliki kesempatan yang sama untuk dipilih menjadi sampel. Dalam menentukan sampel yaitu dengan menggunakan Purposive Sampling, yaitu teknik pengambilan sampel dengan memilih berdasarkan penilaian peneliti, yakni sampel yang dipilih adalah pihak yang tepat untuk dijadikan sampel penelitiannya yaitu pengunjung Taman Sari Rasa Waterpark yang pernah berkunjung minimal 1 kali, dan berumur minimal 16 tahun (Sugiyono, 2004).

\section{D.Definisi Operasional Variabel}

Definisi operasional adalah suatu definisi yang diberikan kepada suatu variabel/konstruk dengan cara memberikan arti/menspesifikasikan kegiatan ataupun memberikan suatu operasional yang diperlukan untuk/konstruk variabel tersebut (Nazir, 2005). Variabel yang digunakan dalam penelitian ini adalah:

1. Perceived Quality $\left(X_{1}\right)$ yaitu: persepsi konsumen tentang kualitas suatu barang atau jasa.

Variabel perceived quality terdiri dari 7 indikator, yaitu:

1. kualitaslay outwahana yang baik.

2. kualitas layanan yang baik.

3. kualitas pengamanan yang baik.

4. kualitas air yang baik.

5. kondisi alat permainan yang baik.

6. keramahan karyawan terhadap para pengunjung.

7. respon karyawan terhadap complain.

2. Perceived Sacrifice $\left(\mathrm{X}_{2}\right)$ yaitu: persepsi tentang pengorbanan yang harus dibayar oleh konsumen demi mendapatkan barang atau jasa tersebut.

Variabel perceived sacrifice terdiri dari 3 indikator, yaitu: 
1. pengorbanan yang dilakukan konsumen untuk mendapatkan barang atau jasa yang di inginkan.

2. mengantri terlebih dahulu.

3. pengorbanan secara fisik misalnya menyetir sendiri ke tempat tersebut ataupun menggunakan angkutan umum.

3. Perceived Value $\left(\mathrm{X}_{3}\right)$, yaitu: nilai yang didapat konsumen dengan mempertimbangkan antara cost yang dikeluarkan dengan benefit yang diperoleh.

Variabel perceived value terdiri dari 4 indikator, yaitu:

1. uang yang dikeluarkan sebanding dengan nilai manfaat yang diperoleh.

2. wahana yang dipilih merupakan pilihan yang baik untuk berekreasi.

3. uang yang dikeluarkan sebanding dengan kualitas.

4. banyaknya berbagai macam pilihan wahana permainan dengan harga yang terjangkau.

4. Perceived Price Fairness $\left(X_{4}\right)$, yaitu: kewajaran harga, perbandingan prosedur harga yang terkait dengan standar, referensi atau norma.

Variabel Price Fairness terdiri 5 indikator, yaitu:

1. keterjangkauan harga.

2. kesesuaian harga dengan layanan.

3. kesesuian harga dengan fasilitas yang ditawarkan.

5. Customer Satisfaction (Y), yaitu: kepuasan pelanggan, perasaan senang atau kecewa seseorang yang timbul karena membandingkan kinerja yang di persepsikan produk (atau hasil) terhadap ekspektasi mereka.

Variabel Customer Satisfaction terdiri 4 indikator, yaitu:

1. pembelian kembali.

2. ketersediaanpelanggan untuk merekomendasikan kepada orang lain.

3. fasilitas pelayanan sesuai harapan pelanggan.

4. pengalaman yang memuaskan bagi pengunjung

\section{E.Uji Instrumen Penelitian Uji Validitas}

Uji validitas digunakan untuk menguji apakah pertanyaan pada suatu kuesioner mampu mengungkapkan sesuatu yang akan diukur oleh kuesioner tersebut. Penelitian ini menggunakan uji validitas dengan menggunakan korelasi antar skor butir pertanyaan dengan total skor konstruk atau variabel valid (Ghozali, 2011). Uji signifikansi dilakukan dengan membandingkan nilai $r$ hitung dengan $r$ tabel untuk degree of freedom (df) $=n-2$, dalam hal ini $n$ adalah jumlah sampel.

\section{Uji Reliabilitas}

Reliabilitas menunjukan pada suatu pengertian bahwa suatu instrumen cukup dapat dipercaya untuk digunakan sebagai alat pengumpul data karena instrumen tersebut sudah baik.Instrumen yang baik tidak dapat bersifat tendensius mengarahkan responden untuk memilih jawaban-jawaban tertentu.Jika $r_{\text {hitung }}>r_{\text {tabel }}$ pada taraf signifikan $5 \%$ berarti item (butir soal) reliabel dan sebaliknya bila $r_{\text {hitung }}<r_{\text {tabel }}$ pada taraf signifikan $5 \%$ maka butir soal tersebut tidak reliabel.

\section{F.Uji Asumai Klasik Uji Normalitas}

Menurut Ghozali (2009), uji normalitas bertujuan untuk menguji apakah dalam model regresi, variabel terikat dan variabel bebas keduanya mempunyai distribusi normal atau tidak. Model regresi yang baik adalah apabila keduanya mempunyai distribusi normal atau mendekati normal, tidak mengandung multikolinearitas dan heteroskedastisitas 


\section{Uji Multikoliniearitas}

Uji Multikolinearitas bertujuan untuk menguji apakah dalam model regresi ditemukan adanya korelasi antar variabel bebas (independen).Model regresi yang baik seharusnya tidak terjadi korelasi diantara variabel bebas (independen).Nilai cutoof yang umum dipakai untuk menunjukan ada tidaknya multikolinearitas adalah nilai Tolerance $\leq 0.10$ atau VIF $\geq 10$.(Ghozali, 2001).

\section{Uji Autokorelasi}

Uji Autokorelasi bertujuan menguji apakah dalam model regresi linear ada korelasi antara kesalahan pengganggu pada periode $t$ dengan kesalahan pengganggu pada periode $t-1$ (sebelumnya).Jika terjadi korelasi, maka dinamakan ada problem autokorelasi.Cara yang dapat digunakan untuk mendeteksi ada atau tidaknya autokorelasi yaitu dengan uji Durbin-Watson. (DW test)

\section{Uji Heteroskedastisitas}

Uji ini dilakukan untuk menganalisis apakah dalam model regresi terdapat ketidaksamaan variance dari residual satu pengamatan ke pengamatan yang lain. Kita dapat melihatnya dari grafik plot antara nilai prediksi suatu variabel dependen dengan residualnya.

\section{G.Analisis Regresi Linier Berganda}

Menurut Sugiyono (2010) analisis regresi linier berganda adalah dimana variabel terikatnya ( $Y$ ) dihubungkan dengan satu variabel bebasnya $(X)$. Persamaan regresinya sebagai berikut:

$Y=\alpha+\beta_{1} X_{1}+\beta_{2} X_{2}+\beta_{3} X_{3}+\beta_{4} X_{4}+e$

Keterangan:

$Y=$ Customer satisfaction

$\alpha=$ Konstanta

$\beta_{1}=$ Koefisien regresi dari variabel $X_{1}$, Perceived Quality

$\beta_{2}=$ Koefisien regresi dari variabel $X_{2}$, Perceived Sacrifice

$\beta_{3}=$ Koefisien regresi dari variabel $X_{3}$, Perceived Value

$\beta_{4}=$ Koefisien regresi dari variabel $X_{4}$, Price Fairness

$\mathrm{X}_{1}=$ Perceived Quality

$X_{2}=$ Perceived Sacrifice

$\mathrm{X}_{3}=$ Perceived Value

$\mathrm{X}_{4}=$ Price Fairness

$e=$ Standar kesalahan (error)

\section{H.Uji Parsial (uji t )}

Uji t dilakukan untuk mengetahui pengaruh masing-masing variabel independen terhadap variabel dependen. Adapun langkah-langkah yang harus dilakukan dalam uji ini adalah sebagai berikut:

a). Merumuskan hipotesis

1. Ho : $b_{1} \leq 0$, artinya perceived quality tidak berpengaruh secara positif terhadap customer satisfaction.

$\mathrm{Ha}: \mathrm{b}_{1}>0$, artinya perceived quality berpengaruh secara positif terhadap customer satisfaction.

2. Ho: $b_{2} \leq 0$, artinya perceived sacrifice tidak berpengaruh secara negatif terhadap customer satisfaction.

$\mathrm{Ha}: \mathrm{b}_{2}>0$, artinya perceived sacrifice berpengaruh secara negatif terhadap customer satisfaction.

3. Ho : $b_{3} \leq 0$, artinya perceived value tidak berpengaruh secara positif terhadap customer satisfaction.

$\mathrm{Ha}: b_{3}>0$, artinya perceived value berpengaruh secara positif terhadap customer satisfaction.

4. Ho : $b_{4} \leq 0$, artinya price fairness tidak berpengaruh secara positif terhadap customer satisfaction.

$\mathrm{Ha}: \mathrm{b}_{4}>0$, price fairness berpengaruh secara positif terhadap customer satisfaction

b). Membandingkan hasil thitung dengan $t_{\text {tabel }}$ dengan kriteria sebagai berikut: 


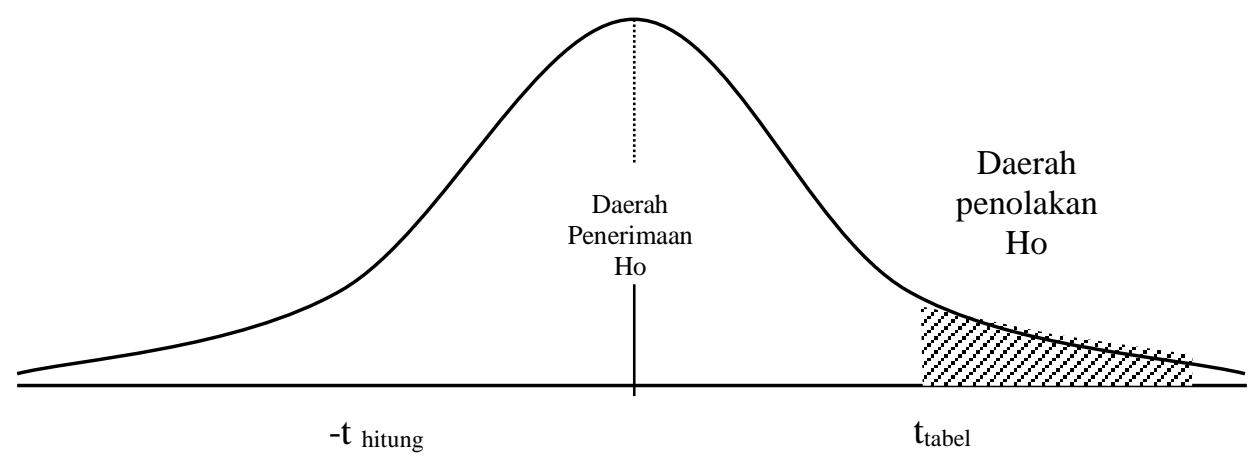

1. Taraf signifikan $(a=0,05)$

Kurva Normal Uji t

2. Distribusi t dengan derajat kebebasan $(n)$

3. Ho diterima jika $-t$ tabel $\leq t$ hitung $\leq t$ tabel

4. Ho ditolak jika $-t$ tabel $<t$ tabel atau $t$ hitung $>t t_{\text {abel }}$

\section{I.Uji Simultan (uji F)}

Uji F dilakukan untuk melihat ketepatan ramalan dari koefisien persamaan melalui data yang terkumpul.Uji statistik $\mathrm{F}$ pada dasarnya menunjukan apakah semua variabel independen mempunyai pengaruh secara simultan terhadap variabel dependen.

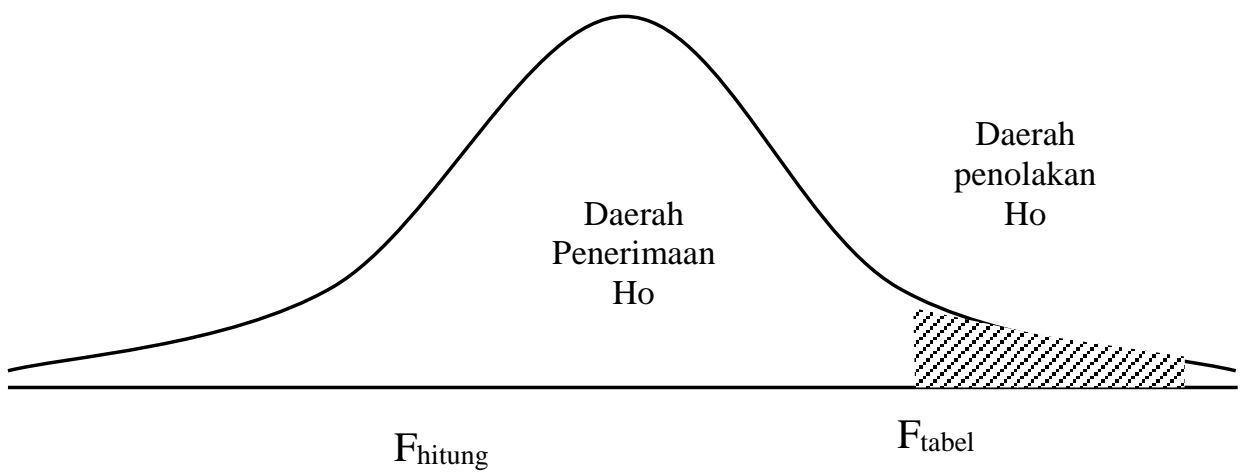

\section{Kurva Normal Uji F}

1. Apabila $F_{\text {hitung }}>F_{\text {tabel, }}$ maka Ho ditolak dan Ha diterima

2. ApabilaF tabel $\leq \mathrm{F}_{\text {hitung, }}$, maka Ho diterima dan Ha ditolak.

\section{J.Koefisien Determinasi Adjusted ( $\left.\mathbf{R}^{2}\right)$}

Koefisien determinasi adjusted $\left(\mathrm{R}^{2}\right)$ pada intinya digunakan untuk mengukur seberapa jauh kemampuan model dalam menerangkan variasi variabel dependen. Nilai koefisien determinasi adalah nol dan satu.Nilai yang mendekati satu berarti variabel-variabel independen memberikan hampir semua informasi yang dibutuhkan untuk memprediksi variasi variabel dependen.

\section{IV.HASIL DAN PEMBAHASAN}

\section{A.Uji Validitas}

Hasil perhitungan menunjukkan hasil bahwa semua variabel yang digunakan dalam penelitian ini adalah mempunyai korelasi yang lebih besar dari $r$ tabel yaitu 0,166 .Sehingga semua indikator dalam penelitian ini adalah valid. 


\section{B.Uji Reliabilitas}

Reliabilitas adalah tingkat kestabilan dari suatu alat ukur dalam mengukur suatu gejala.Semakin tinggi reliabilitas, maka semakin tinggi tingkat kemantapan hasil pengukuran. Berdasarkan perhitungan reliabilitas diperoleh koefisien realibilitas untuk masing-masing instrumen yaitu perceived qualitysebesar 0,847, perceived sacrificesebesar 0,634, perceived value sebesar 0,804 , price fairness sebesar 0,828 , dan customer satisfaction sebesar 0,757 lebih besar dari $r$ tabel 0,166 . Dengan demikian instrumen penelitian dinyatakan reliabel (andal).

\section{C.Uji Asumsi Klasik \\ Uji Normalitas}

Uji normalitas bertujuan untuk menguji apakah dalam model regresi, variabel penggunaan atau residual memiliki distribusi normal atau tidak. Dengan melihat nilai asymp.sig.sebesar 0,614 maka dapat disimpulkan bahwa data penelitian telah terdistribusi normal, karena nilai asymp.sig.lebih dari 0,05 .

\section{Uji Multikoliniearitas}

Hasil perhitungan nilai Tolerance yang menunjukan tidak ada variabel independen yang memilki nilai Tolerance kurang dari 0,10 . Hasil perhitungan nilai (VIF) juga menunjukan hal yang sama tidak ada satu variabel independen yang memiliki nilai VIF lebih dari 10. Jadi dapat disimpulkan bahwa tidak ada multikolinearitas antar variabel independen dalam model regresi.

\section{Uji Autokorelasi}

Hasil perhitungan menunjukkan hasil bahwa nilai Durbin-Watson (DW test) adalah 2,125. Oleh karena itu nilai DW 2,125 lebih besar dari batas atas (du) 1,7575 dan kurang dari 4 - 1,7575 (4-du) = 2,2425, maka dapat disimpulkan bahwa tidak ada autokorelasi positif atau negatif atau dapat disimpulkan tidak terdapat autokorelasi.

\section{Uji Heteroskedastisitas}

Hasil perhitungan menunjukan hasil bahwa nilai signifikansi secara keseluruhan $>0,05$ yang artinya model regresi diasumsikan tidak terdapat heteroskedastisitas.

\section{D.Analisis Regresi Linier Berganda}

Model regresi linier berganda dalam penelitian ini adalah:

$Y=1,458+0,219 X_{1}-0,013 X_{2}+0,188 X_{3}+0,212 X_{4}+e$

Persamaan tersebut dapat dijabarkan sebagai berikut:

a. Konstanta sebesar 1,458 satuan artinya jika perceived quality $\left(X_{1}\right)$, perceived sacrifice $\left(X_{2}\right)$, perceived value $\left(\mathrm{X}_{3}\right)$, price fairness $\left(\mathrm{X}_{4}\right)$ tidak ada perubahan.

b. Koefisien variabel perceived quality sebesar 0,219 satuan artinya customer satisfactionmeningkat sebesar 0,219 satuan apabila variabel perceived qualitynaik satu satuan dengan variabel perceived sacrifice, perceived value, danprice fairness bernilai konstan.

c. Koefisien variabel perceived sacrifice sebesar $-0,013$ satuan artinya customer satisfaction menurun sebesar $-0,013$ satuan apabila variabel perceived sacrifice naik satu satuan dengan variabel perceived quality, perceived value, dan price fairnessbernilai konstan.

d. Koefisien variabel perceived value sebesar 0,188 satuan artinya customer satisfactionmeningkat sebesar 0,188 satuan apabila variabel perceived value naik satu satuan dengan variabel perceived quality, perceived sacrifice, dan price fairness bernilai konstan.

e. Koefisien variabel price fairness sebesar 0,212 satuan artinya customer sebesar satisfactionmeningkat 0,212 satuan apabila variabel price fairnesss naik satu satuan dengan variabel perceived quality, perceived sacrifice, dan perceived value bernilai konstan.

\section{E.Koefisien Determinasi}

Koefisien determinasi (adjusted $\mathrm{R}^{2}$ ) sebesar 0,250. Hal ini berarti 25,0\% variabel customer satisfaction di Taman Sari Rasa Waterparkdapat dijelaskan oleh ke empat variabel independen yaitu, 
perceived quality, perceived sacrifice, perceived value, dan price fairness. Sedangkan selisihnya sebesar $75,0 \%$ dijelaskan oleh sebab lain diluar model (diluar penelitian ini).

\section{F.Pembahasan}

Hasil pengujian hipotesis pertama didapat hasil bahwa variabel perceived quality berpengaruh positif dan signifikan terhadap customer satisfaction. Jika perceived quality semakin tinggi, maka akan mengakibatkan semakin tinggi kesediaan konsumen untuk berkunjung ke Taman Sari Waterpark untuk mencapai kepuasaan konsumen, karena kualitas (quality) yang diberikan Taman Sari Rasa Waterpark terhadap konsumen yang baik memberikan kesan tersendiri.

Hasil pengujian hipotesis kedua didapat hasil bahwa variabel perceived sacrifice berpengaruh negatif namun tidak signifikan terhadap customer satisfaction.Berdasarkan analisis pertanyaan terbuka yang diajukan para konsumen telah melakukan pengorbanan seperti mengantri pada saat hari-hari tertentu misalnya hari-hari liburan, pengorbanan uang mereka terkuras habis, menyita waktu dan materi mereka, semakin tinggi perceived sacrifice maka semakin rendah kepuasan konsumennya, sehingga bila ingin mendapatkan kepuasan konsumen yang tinggi tentu kita harus menekan perceived sacrifice serendah mungkin.

Hasil pengujian hipotesis ketiga didapat hasil bahwa variabel perceived value berpengaruh positif namun tidak signifikan terhadap customer satisfaction.Berdasarkan analisis pertanyaan terbuka yang diajukan mayoritas pengunjung mengharapkan kepada pihak Taman Sari Rasa Waterpakmenambah koleksi binatang-binatangnya, taman untuk membaca, penataan tempat dibuat variatif atau mengandung unsur seni dan keindahan, menambah wahana-wahana lain, semakin tinggi perceived value maka semakin tinggi kepuasan konsumennya.

Hasil pengujian hipotesis keempat didapat hasil bahwa variabel price fairness berpengaruh terhadap customer satisfaction.Berdasarkan analisis pertanyaan terbuka yang diajukan kepada para pengunjung, mereka mengatakan bahwa harga tiket yang diberikan terjangkau, harga sesuai dengan layanan yang diberikan, harga sesuai dengan fasilitas yang ditawarkan, semakin tinggi price fairness maka akan mengakibatkan semakin tinggi kesediaan konsumen untuk berkunjung ke Taman Sari Waterpark untuk mencapai kepuasaan konsumen.

Hasil pengujian hipotesis kelima tentang pengaruh perceived quality, perceived sacfifice, perceived value, dan price fainess terhadap customer satisfaction, hasil pengujian hipotesis kelima didapat hasil bahwa keempat variabel tersebut memiliki pengaruh secara simultan terhadap customer satisfaction.

\section{V.KESIMPULAN DAN SARAN}

\section{Kesimpulan}

1. Perceived Quality berpengaruh positif dan signifikan.

2. Perceived Sacrifice berpengaruh negatif namun tidak signifikan

3. Perceived Value berpengaruh positif namun tidak signifikan

4. Price Fainess berpengaruh positif dan signifikan

5. Perceived Quality, Perceived Sacrifice, Perceived Value, dan PriceFainess secara simultan berpengaruh terhadap Customer Satisfaction 
1. Saran kepada perusahaan

\section{Saran}

Pihak Taman Sari Rasa Waterpark diharapkan lebih meningkatkan kualitas dalam pelayanan dari waktu ke waktu, agar konsumen lebih merasa nyaman dengan pelayanan, nilai, dan harga yang diberikan dan memberikan kesan tersendiri sehingga kepuasaan pelanggan terpenuhi dan akan lebih sering untuk berkunjung kembali.

2. Saran kepada peneliti selanjutnya

Peneliti selanjutnya diharapkan menambahkan jumlah variabel seperti corporate image dan lokasi agar peneliti selanjutnya jauh lebih mengetahui tantang customer satisfaction (kepuasan konsumen).

\section{Daftar Pustaka}

Algifari, 2000.Analisis Statistik untuk Bisnis: Regresi Korelasi dan Nonparametrik, BPFE. Yogyakarta Adi.2012. Pengaruh Kualitas Produk dan Harga terhadap loyalitas dengan Kepuasan Konsumen sebagai Variabel Intervening. Manajemen Analisis Jurnal. Universitas Negri Semarang.

Ananti, Sutanto. 2008.PengaruhService Quality Dan Perceived Value Terhadap Kepuasan Dan Loyalitas Konsumen ApartemenDi Kota Surabaya. Tesis.Universitas Katolik Widya Mandala Surabaya.

Arikunto. 2010. Prosedur Penelitian Satu Pendekatan Praktek. Edisi Revisi. PT Rineka Cipta. Jakarta.

Atmaja, Dharmadewi. 2011. Pengaruh Kewajaran Harga, Citra Perusahaan Terhadap Kepuasan dan Loyalitas Pengguna Jasa Penerbangan Domestik Garuda Indonesia Di Denpasar.Tesis. Universitas Udayana Denpasar.

Ayu, Yohana. 2009. Pengaruh Perceived Quality, Perceived Value, Brand Preference, Customer Satisfaction, dan Customer Loyality pada Repurchase Intention. Jurnal Manajmen Pemasaran. Universitas Sebelas Maret. Surakarta.

Ghozali, 2001.Aplikasi Analisis Multivariate dengan Program SPSS. Badan Penerbit UNDIP: Semarang.

2009. Aplikasi Analisis Multivariate dengan Program SPSS. Badan Penerbit UNDIP: Semarang.

2011. Aplikasi Analisis Multivariate dengan program IBM SPSS 19 Edisi Kelima. Badan Penerbit UNDIP: Semarang.

Kotler, dan Keller. 2009. Manajemen Pemasaran. Diterjemahkan oleh Sabran Bob. Edisi Tiga Belas. Jilid 1, Erlangga: Jakarta. 2007. Manajemen Pemasaran Jilid 1, Edisi Kedua Belas. Indeks.

Kotler dan Amstrong, 2003.Dasar-dasar Pemasaran.Indeks.

Krisno dan Samuel. 2013. Pengaruh Perceived Quality, Perceived Sacrifice, dan Perceived Value terhadap Customer Satisfaction di Informa Innovative Furnishing Pakuwon City Surabaya. Jurnal Manajemen Pemasaran, Vol. 1, No. 1, (2013) 1-12.

Lupiyoadi, Rambat, 2001. Manajemen Pemsaran Jasa Teori dan Praktik. Salemba Empat: Jakarta.

Moch, Nazir. 2005. Metode Penelitian. Salemba Empat: Jakarta.

Nurdiansah, Cepi. 2013. Analisis Pengaruh Kewajaran Harga, Kualitas Layanan Dan Kualitas Produk Terhadap Kepuasan Pelanggan Dalam Upaya Meningkatkan Loyalitas Pelanggan Pada Rumah Makan "Angkringan Cekli" Kudus. Skripsi. Universitas Diponegoro.

Singarimbun, Masri dan Effendi, Sofyan. 1995. MetodePenelitian Survei. LP3ES: Jakarta.

Sugiyono. 2004. Metode Penelitian Bisnis. Alfabeta: Bandung.

2010. Metodologi Penelitian Kuantitatif Kualitatif dan R\&D, Alfabeta: Bandung.

Supranto.2011. Pengukuran Tingkat kepuasan Pelanggan Untuk Menaikan Pangsa Pasar. Rineka Cipta: Jakarta. 
Suprapti, Lilik. 2010. Analisis Pengaruh Brand Awareness, Perceived Value, Organizational Association dan Perceived Quality terhadap Keputusan PembelianKonsumen.Skripsi. Universitas Diponegoro.

Sutanto,Roni.2010.Analisis Pengaruh Reference Price dan Actual Price terhadap Perceived Value dan Willingness to Buy (Studi pada Promo Diskon 50\% Produk Fashion Matahari Departement Store di Kota Surakarta.Skripsi. Universitas Sebelas Maret.

Terry George. R \& Rue Leslie. W. 2011. Dasar-dasar Manajemen. Bumi Aksara: Jakarta.

Tjiptono, Fandy. 2007. Pemasaran Jasa. Bayumedia Publishing: Jawa Timur 2008. Strategi Pemasaran. Andi: Yogyakarta.

Widiarso, Wahyu. 2011. Keterkaitan antara Variabel Perceived Value, Customer Satisfaction, dan Corporate Image dengan Brand Loyalty, Repurchase Intention, dan Word of Mouth (Studi Kasus pada Pengguna Handphone Blackberry di Kota Surakarta. Jurnal Manajemen Pemasaran. Universitas Sebelas Maret. Surakarta.

http://id.wikipedia.org/wiki/Rekreasi diakses pada tanggal 17 Oktober 2014

www.tamansarirasa.com diakses pada tanggal 8 Oktober 2014 